\title{
Professional Demographic Factors That Influence Iranian Auditors' Perceptions Of The Fraud-Detecting Effectiveness Of Red Flags
}

\author{
Weifang Yang, University of Texas - Pan American, USA \\ Glen D. Moyes, University of Texas - Pan American, USA \\ Hamed Hamedian, University of Ahvaz, Iran \\ Azar Rahdarian, University of Ahvaz, Iran
}

\begin{abstract}
The purpose of this study is to explore the relationship between professional demographic factors concerning external and internal auditors and the perceived level of effectiveness of the Statement of Auditing Standard (SAS) No. 99 red flags in detecting fraudulent financial reporting activities as perceived by external and internal auditors. The six hypotheses are: (1) the type of auditors using red flags to detect fraud, (2) highest degrees received by auditors, (3) areas that auditors majored in at universities, (4) auditors' accumulated knowledge of red flags, (5) auditors who have or have not used red flags to detect fraud, and (6) auditors who have or have not received inhouse red flag training. The six hypotheses explore how six professional demographic factors may influence the level of fraud-detecting effectiveness of the SAS No. 99 red flags as perceived by 227 external and internal auditors in Iran. The results of this study indicate that all six hypotheses were accepted. In conclusion, the level of fraud-detecting effectiveness of these red flags as perceived by the Iranian auditors may be influenced by the following factors: (1) the type of auditors, (2) the highest degrees received by auditors, (3) areas that auditors majored in at universities, (4) knowledge about red flags accumulated by auditors, (5) auditors who have or have not previously used red flags to detect fraud, and (6) auditors who have or have not previously received in-house red flag training.
\end{abstract}

Keywords: Red Flags, Fraud Detection, Level of Effectiveness, External and Internal Auditors, CPAs, Iran

\section{INTRODUCTION}

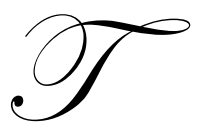

he objective of this study was to determine the degree of influence that professional demographic factors may exert on the level of fraud-detecting effectiveness of red flags in detecting fraudulent financial reporting activities as perceived by the external and internal auditors in Iran. In this study, 18 professional demographic factors were statistically analyzed as to their possible influence upon Iranian external and internal auditors using red flags to detect fraudulent financial activities, while conducting financial statement audits of their corporate audit clients. Statement of Auditing Standard (SAS) No. 99 requires external auditors to use 42 red flags in financial statement audits to detect fraudulent financial reporting activities (AICPA, 2009). Internal auditors may assist external auditors in conducting financial statement audits, so the extremely high audit fees that CPA firms charge their corporate clients may be decreased partially. From the 227 Iran auditors (external and internal) surveyed, a total of 36 red flags were investigated to determine if any of the 18 professional demographic factors associated with the auditors appear to influence the level of effectiveness of the 36 red flags to detect fraud as perceived by the external and internal auditors surveyed in Iran. 
The 18 professional demographic factors are as follows: (1) gender, (2) type of auditor, (3) age, (4) highest degree received, (5) areas that auditors majored in at universities, (6) year of graduation, (7) knowledge of red flags, (8) how often auditors use red flags, (9) have auditors used red flags previously to detect fraud, (10) have auditors previously attended red flag conferences, (11) have auditors previously received in-house red flag training, (12) position or job title of external auditors, (13) position or job title of internal auditors, (14) type of firm employing auditors, (15) number of years of internal auditing experience, (16) number of years of external auditing experience, (17) number of years of total auditing experience, and (18) do auditors want to teach accounting courses.

This study explored the relationship between 18 professional demographic factors concerning auditors and the level of effectiveness of the 36 SAS No. 99 red flags in detecting fraudulent financial reporting activities as perceived by Iranian auditors. Out of the 18 professional demographic factors, six factors were selected by using Cluster Analysis. The six hypotheses were investigated to determine how the six professional demographic factors may influence the level of fraud-detecting effectiveness of these 36 red flags as perceived by 227 external and internal auditors surveyed in Iran. These six professional demographic factors are: (1) the type of auditors, (2) highest degrees received by auditors, (3) areas that auditors majored in at universities, (4) accumulated knowledge of red flags by auditors, (5) auditors who have or have not previously used red flags to detect fraud, and (6) auditors who have or have not previously received in-house red flag training

\section{PRIOR STUDIES}

This Iranian study is very similar to a large study conducted in the United States. From the American study, six articles were previously written and published in journals. The results and conclusions from the six prior articles published can be generally summarized by the following two statements: First, the level of fraud-detecting effectiveness of the 42 SAS No. 99 red flags can be classified by statistical testing into three categories: more effective, average effectiveness, and less effective, as perceived by external auditors, internal auditors, and both external and internal auditors combined (Moyes, et al., 2005; Moyes et al., 2006b; Moyes et al., 2007; and Moyes, 2008). Second, numerous significant differences exist between external and internal auditors concerning their perceptions of the level of fraud-detecting effectiveness of each of the 42 SAS No. 99 red flags that are required to be used in financial statement audits to detect fraudulent financial reporting activities (Lin et al., 2006; Moyes, 2006a). Each of the six articles provided unique and specific results and conclusions that differentiate it from the other articles.

Albrecht and Romney (1986) showed that partners perceived only one-third of the red flags as being considered significant predictors of fraud, which tended to be considered as personal characteristics of management rather than company-specific factors. Indicators of fraud concerning management are classified as the SAS No. 99 Attitude and Rationalization red flags.

Heiman-Hoffman and Morgan (1996) found that red flags did carry different weights as perceived by the sample of auditors surveyed and discovered that the auditors tended to rate "management attitudes" as the single most important category of red flags when compared to other organizational variables. They concluded management attitudes represented one of the three categories of red flags which are required to be used by external auditors in conducting financial statement audits according to the SAS No. 99 (AICPA, 2009).

Apostolou et al. (2001) surveyed both internal and external auditors. All auditors were requested to determine the importance of the 25 red flags included in SAS No. 82 (AICPA, 2009). Both management characteristics and the influence over the control environment were considered the highest rated indicators (red flags) by the auditors surveyed. No significant differences were found between internal and external auditors.

Gramling and Myers (2003) examined internal auditors' perceptions concerning 43 red flags and indicated the most important red flags involve factors related to attitude or rationalization. Out of the top 15 red flags, six represented Attitude or Rationalization red flags, three represented Incentive red flags, and six represented Opportunity red flags. In addition, four out of the six Attitude or Rationalization red flags were determined to be more important than the other red flags. 
Pincus (1989) investigated the efficacy of the use of red flags as perceived by auditors and noted that approximately half of the respondents indicated that red flag questionnaires assisted auditors in fraud assessment, because these auditors considered red flags as very important tools used in the financial statement audits. For the other respondents, one conclusion may be that auditors who do not use red flag questionnaires may indicate they do not understand red flags to be good indicators of fraudulent financial activities.

Church et al. (2001) found that internal auditors considered certain red flags to be more probable for detecting fraud. These two red flags are related to income-surpassing expectations and managers' bonuses based on earnings.

\section{RESEARCH MODELS}

In this Iranian study, the following six hypotheses will be statistically tested to be either accepted or rejected. Out of the 18 professional demographic factors, Cluster Analysis selected the six factors for statistical analysis, which included the MANOVA. The six professional demographic factors selected are: (1) type of auditors, (2) highest degrees received by auditors, (3) areas that auditors majored in at universities, (4) different amounts of knowledge accumulated by auditors about red flags, (5) auditors have or have not used red flags to detect fraud, and (6) auditors have or have not received in-house red flag training. The following six hypotheses were written for the six professional demographic factors, which were selected by Cluster Analysis.

Hypothesis 1: There will be differences in the perceived level of effectiveness of red flags in fraud detection between the two types of auditors: external and internal.

Hypothesis 2: There will be differences in the perceived level of effectiveness of red flags in fraud detection among the different types of the highest degrees received by the auditors.

Hypothesis 3: There will be differences in the perceived level of effectiveness of red flags in fraud detection among the different majors declared by the auditors, when they were students at universities.

Hypothesis 4: There will be differences in the perceived level of effectiveness of red flags in fraud detection among the different levels of auditors' accumulated knowledge about red flags.

Hypothesis 5: There will be differences in the perceived level of effectiveness of red flags in fraud detection between auditors who have detected fraud using red flags and auditors who have not detected fraud using red flags.

Hypothesis 6: There will be differences in the perceived level of effectiveness of red flags in fraud detection between auditors who have received in-house red flag training and auditors who have not received in-house red flag training.

\section{METHODOLOGY}

The targeted population in this study was a random sample of audit professionals in the country of Iran. This study attempted to determine which professional factors influence the level of fraud-detecting effectiveness of 36 SAS No. 99 red flags as perceived by Iranian external and internal auditors.

The auditing professionals were surveyed to evaluate the level of effectiveness of the 36 red flags in detecting fraud by using a seven-point Likert scale, which measures the auditors' perceptions of the fraud-detecting effectiveness of each of the 36 red flags. A total of 227 usable questionnaires were collected. In Iran, 450 red flag questionnaires were mailed to external auditors, and another 450 red flag questionnaires were also mailed to internal auditors. As a result, 130 usable questionnaires were collected from the external auditors representing a 29 percent response rate, and 91 usable questionnaires were also collected from the internal auditors representing a 20 percent response rate. 
External and internal auditors' responses on the questionnaires were entered into a SPSS database. The data collected from questionnaires was analyzed by using the following statistical tests: Factor Analysis, Cluster Analysis, and the MANOVA. Factor analysis was used for data reduction which resulted in the 36 red flags being classified into eight factor groups. Cluster Analysis determined the six out of the 18 professional demographic variables which may have significant differences. Six hypotheses were written for those six demographic variables selected. In using Factor Analysis, the factor scores were saved as variables, which were later used as dependent variables in a MANOVA. Next, the averages of the variables loaded to each factor were saved as variables for comparison with the factor score variables. The MANOVA was used to test the six hypotheses. Comparisons were made between the simple averages of only the variables loaded to a factor and the factor scores.

For the MANOVA, the dependent variables used for this study represent the level of effectiveness of each of the 36 red flags in detecting fraud according to the perceptions of external and internal auditors. In using the MANOVA, the independent variables were: (1) type of auditors, (2) highest degrees received by auditors, (3) areas that auditors majored in at universities, (4) accumulated knowledge of red flags by auditors, (5) auditors who have or have not used red flags to detect fraud, and (6) auditors who have or have not received in-house red flag training.

The design of the red flag questionnaire was based on the 36 red flags, which were classified into three SAS No. 99 red flag categories: Pressure, Opportunity and Rationalization. Two types of auditors (external and internal) were surveyed to evaluate the effectiveness of each of the 36 red flags in detecting fraud by using a sevenpoint Likert scale on the red flag questionnaire. The composition of the seven-point Likert scale was as follows: (1) extremely effective (value of 7), (2) very effective (value of 6), (3) mostly effective (value of 5), (4) somewhat effective (value of 4), (5) seldom effective (value of 3), (6) low effective (value of 2), and (7) not effective (value of 1). For example, if the auditor indicated a red flag was "extremely effective," a value of 7 was entered into the SPSS database.

\section{RESULTS}

An exploratory Factor Analysis was conducted on the 36 red flags which reduced 36 red flags as variables into eight factor groups. Each factor group was labeled with a name that was descriptive the red flags as variables which comprised each factor group. The names of the eight factor groups and the explanations of the 36 red flags are shown in Tables 1, 2 and 3. The SAS No. 99 requires external auditors, with or without the assistance of internal auditors, to use red flags during financial statement audits to detect fraudulent financial reporting activities. In Tables 1, 2, and 3, the factor groups are labeled in the left column, and the red flags are shown in the right column. In Tables 1, 2 and 3, PR indicates Pressure red flags, OP indicates Opportunity red flags, and RA indicates Rationalization red flags. In general, the results of this Iran study agreed with the similar results from prior studies conducted in the United States (Lin et al., 2006; Moyes et al., 2005; Moyes, 2006a; Moyes et al., 2006b; Moyes et al., 2007; and Moyes, 2008).

Table 1 shows the 13 Pressure (PR) red flags which have been combined into three factor groups by using Factor Analysis. In Table 1, the three factor groups are labeled as: (1) Management Decisions and Market Changes, (2) CEOs, Directors and Operating Performance, and (3) Listing/Debt Requirements and Profitability.

Table 2 shows the 11 Opportunity (OP) red flags, which have been combined into three factor groups by using Factor Analysis. In Table 2, the three factor groups are labeled as: (1) Transactions, Accounts and Estimates, (2) Oversight and Monitoring, and (3) Organizational Structure and Controls. 
Table 1: 13 Pressure Red Flags Combined into Three Factor Groups

\begin{tabular}{|c|c|}
\hline 3 Factor Groups & 13 Pressure Red Flags \\
\hline \multirow{7}{*}{$\begin{array}{l}\text { PR-1: } \\
\text { Management Decisions } \\
\text { \& Market Changes }\end{array}$} & PR-1-1 High vulnerability to rapid changes in technology, product obsolescence, or interest rates \\
\hline & $\begin{array}{l}\text { PR-1-2 Excessive pressure on operating management or personnel to meet financial targets (sales } \\
\text { and profitability incentive goals) exerted by boards of directors and chief executive officers }\end{array}$ \\
\hline & $\begin{array}{l}\text { PR-1-3 Significant declines in customer demand and increasing business failures in the industry } \\
\text { or overall economy }\end{array}$ \\
\hline & $\begin{array}{l}\text { PR-1-4 Need to obtain additional debt or equity financing of major research and development or } \\
\text { capital expenditures to stay competitive }\end{array}$ \\
\hline & PR-1-5 High degree of competition or market saturation accompanied by declining margins \\
\hline & PR-1-6 New accounting, statutory, or regulatory requirements \\
\hline & $\begin{array}{l}\text { PR-1-7 Significant portions of management's compensation, represented by bonuses and stock } \\
\text { options, being contingent upon achieving aggressive targets for stock price, operating results, } \\
\text { financial position, or cash flow }\end{array}$ \\
\hline \multirow{4}{*}{$\begin{array}{l}\text { PR-2: } \\
\text { CEOs, Directors \& } \\
\text { Operating Performance }\end{array}$} & PR-2-1 Management and/or board directors holding significant financial interests in the entity \\
\hline & $\begin{array}{l}\text { PR-2-2 Management and/or board directors have personally guaranteed significant debts of the } \\
\text { firm }\end{array}$ \\
\hline & $\begin{array}{l}\text { PR-2-3 Recurring negative cash flows from operations or an inability to generate cash flows } \\
\text { while reporting earnings and earnings growth }\end{array}$ \\
\hline & $\begin{array}{l}\text { PR-2-4 Operating losses causing threat of imminent bankruptcy or foreclosure, or hostile } \\
\text { takeover }\end{array}$ \\
\hline \multirow{2}{*}{$\begin{array}{l}\text { PR-3: } \\
\text { Listing/Debt } \\
\text { Requirements \& } \\
\text { Profitability }\end{array}$} & PR-3-1 Marginal ability to meet exchange listing requirements or debt repayment \\
\hline & $\begin{array}{l}\text { PR-3-2 Rapid growth or unusual profitability, especially compared to that of other companies in } \\
\text { the same industry }\end{array}$ \\
\hline
\end{tabular}

Table 2: 11 Opportunity Red Flags Combined into Three Factor Groups

\begin{tabular}{|l|l|}
\hline \multicolumn{1}{|c|}{ 3 Factor Groups } & \multicolumn{1}{c}{ 11 Opportunity Red Flags } \\
\hline $\begin{array}{l}\text { OP-1: } \\
\text { Transactions, Accounts }\end{array}$ & $\begin{array}{l}\text { OP-1-1 Significant, unusual, or highly complex transactions, especially occurring close to year } \\
\text { end that pose difficult "substance over form" questions }\end{array}$ \\
\cline { 2 - 2 } & $\begin{array}{l}\text { OP-1-2 Assets, liabilities, revenues, or expenses based on significant estimates that involve } \\
\text { subjective judgments or uncertainties that are difficult to corroborate }\end{array}$ \\
\cline { 2 - 2 } & $\begin{array}{l}\text { OP-1-3 Significant related-party transactions not in the ordinary course of business or with related } \\
\text { entities that are not audited or audited by another firm }\end{array}$ \\
\cline { 2 - 2 } & $\begin{array}{l}\text { OP-1-4 Domination of management by a single person or small group in a nonowner-managed } \\
\text { business without compensating controls }\end{array}$ \\
\cline { 2 - 2 } $\begin{array}{l}\text { OP-1-5 Significant bank accounts or subsidiary or branch operations in tax-haven jurisdictions for } \\
\text { Oversight \& } \\
\text { Monitoring }\end{array}$ & $\begin{array}{l}\text { OP-2-1 Ineffective board of directors or audit committee oversight over the financial reporting } \\
\text { process and internal control system }\end{array}$ \\
\cline { 2 - 2 } & OP-2-2 Inadequate monitoring of significant internal controls \\
\cline { 2 - 2 } & $\begin{array}{l}\text { OP-2-3 High turnover rates or employment of ineffective accounting, internal audit, or } \\
\text { information technology staff }\end{array}$ \\
\hline \begin{tabular}{l} 
OP-3: $\begin{array}{l}\text { OPganizational } \\
\text { Structure \& Controls }\end{array}$ \\
\cline { 2 - 2 }
\end{tabular} & $\begin{array}{l}\text { OP-3-2 Overly complex organizational structure involving unusual legal entities or managerial } \\
\text { lines of authority }\end{array}$ \\
\cline { 2 - 2 } & $\begin{array}{l}\text { OP-3-3 Difficulty in determining the organization or individuals that have controlling interest in } \\
\text { the entity }\end{array}$ \\
\hline
\end{tabular}

Table 3 shows the 12 Rationalization (RA) red flags, which have been combined into two factor groups by using Factor Analysis. In Table 3, the two factor groups are labeled as: (1) Auditors and Managers, and (2) Management Involvement. 
Table 3: 12 Rationalization Red Flags Combined into Two Factor Groups

\begin{tabular}{|c|c|}
\hline 2 Factor Groups & 12 Rationalization Red Flags \\
\hline \multirow[t]{8}{*}{$\begin{array}{l}\text { RA-1: } \\
\text { Auditors \& Managers }\end{array}$} & $\begin{array}{l}\text { RA-1-1 Unreasonable demands on the auditor, such as unreasonable time constraints regarding the } \\
\text { completion of the audit or the issuance of the auditor's report }\end{array}$ \\
\hline & $\begin{array}{l}\text { RA-1-2 Frequent disputes with the current or predecessor auditor on accounting, auditing, or } \\
\text { reporting matters }\end{array}$ \\
\hline & $\begin{array}{l}\text { RA-1-3 Domineering management behavior in dealing with the auditor, especially involving } \\
\text { attempts to influence the scope of the auditor's work }\end{array}$ \\
\hline & $\begin{array}{l}\text { RA-1-4 Formal or informal restrictions on the auditor that inappropriately limit his access to } \\
\text { people or information or limit his ability to communicate effectively with the board of directors or } \\
\text { the audit committee }\end{array}$ \\
\hline & $\begin{array}{l}\text { RA-1-5 A practice used by management of committing to analysts, creditors, and other third } \\
\text { parties to achieve aggressive or unrealistic forecasts }\end{array}$ \\
\hline & $\begin{array}{l}\text { RA-1-6 Known history of violations of securities law, or claims against the entity, its senior } \\
\text { management, or board directors alleging fraud or violations of securities laws }\end{array}$ \\
\hline & $\begin{array}{l}\text { RA-1-7 An interest by management employing inappropriate means to minimize reported earnings } \\
\text { for tax-motivated reasons }\end{array}$ \\
\hline & $\begin{array}{l}\text { RA-1-8 Management failure to correct known reportable conditions in internal controls in a timely } \\
\text { basis }\end{array}$ \\
\hline \multirow[t]{4}{*}{$\begin{array}{l}\text { RA-2: } \\
\text { Management } \\
\text { Involvement }\end{array}$} & $\begin{array}{l}\text { RA-2-1 Ineffective communication, implementation, support, or enforcement of the entity's values } \\
\text { or ethical standards by management or the communication of inappropriate values or ethical } \\
\text { standards }\end{array}$ \\
\hline & $\begin{array}{l}\text { RA-2-2 Excessive interest by management in maintaining or increasing the entity's stock price or } \\
\text { earnings trend }\end{array}$ \\
\hline & $\begin{array}{l}\text { RA-2-3 Nonfinancial management's excessive participation in the selection of accounting } \\
\text { principles or the determination of significant estimates }\end{array}$ \\
\hline & $\begin{array}{l}\text { RA-2-4 Recurring attempts by management to justify marginal or inappropriate accounting on the } \\
\text { basis of materiality }\end{array}$ \\
\hline
\end{tabular}

All eight factor groups shown in Tables 1, 2, and 3 were used in the data analysis. In Tables 1, 2, and 3, these eight factor groups are classified into the three following SAS No. 99 categories: (1) Pressure red flags indicated by PR, (2) Opportunity red flags indicated by OP and (3) Rationalization red flags indicated by RA. In addition, the 36 red flags are also shown in Tables 1,2 and 3.

Hypothesis 1: Professional Demographic Factor - Type of Auditors (External and Internal)

In the first hypothesis, it is proposed that different types of Iranian auditors (external and internal) will have different levels of perceived effectiveness for each of the 36 red flags. In this study, 91 internal auditors and 130 external auditors completed usable red flag questionnaires, from which the SPSS database was established for data analysis. The MANOVA, which used factor scores, is shown in Table 4. As a professional demographic factor, the type of auditors influences the perceived level of fraud-detecting effectiveness of three red flag factor groups: (1) PR FacScore2: CEOs, Directors and Operating Performance, (2) OP FacScore2: Oversight and Monitoring, and (3) OP FacScore3: Organizational Structure and Controls. Three factor groups include 10 red flags, of which seven red flags are significant and three red flags are marginally significant.

Table 4: Tests of Between-Subjects Effects using Factor Scores

\begin{tabular}{|l|c|c|c|c|c|}
\hline \multicolumn{1}{|c|}{ Dependent Variable } & $\begin{array}{c}\text { Type III Sum } \\
\text { of Squares }\end{array}$ & df & $\begin{array}{c}\text { Mean } \\
\text { Square }\end{array}$ & $\begin{array}{c}\text { F } \\
\text { Value }\end{array}$ & Sig. \\
\hline PR FacScore2 - CEO, Directors \& Operating Performance & 7.442 & 1 & 7.442 & 7.596 & .006 \\
\hline OP FacScore2 - Oversight \& Monitoring & 2.702 & 1 & 2.702 & 2.804 & .095 \\
\hline OP FacScore3 - Organizational Structure \& Controls & 6.915 & 1 & 6.915 & 7.213 & .008 \\
\hline
\end{tabular}


The MANOVA using simple averages of the factor groups is shown in Table 5. In reference to Table 5, the type of auditors influences the perceived level of fraud-detecting effectiveness of two red flag factor groups: (1) CEOs, Directors and Operating Performance, and (2) Organization Structure and Controls. These two groups included seven red flags, which are all significant.

Table 5: Tests of Between-Subjects Effects using Simple Averages of Factors

\begin{tabular}{|l|c|c|c|c|c|}
\hline \multicolumn{1}{|c|}{ Dependent Variable } & $\begin{array}{c}\text { Type III Sum } \\
\text { of Squares }\end{array}$ & df & $\begin{array}{c}\text { Mean } \\
\text { Square }\end{array}$ & $\begin{array}{c}\text { F } \\
\text { Value }\end{array}$ & Sig. \\
\hline PR FacAverage2 - CEOs, Directors \& Operating Performance & 4.700 & 1 & 4.700 & 5.235 & .023 \\
\hline OP FacAverage3 - Organizational Structure \& Controls & 4.439 & 1 & 4.439 & 5.950 & .015 \\
\hline
\end{tabular}

In Table 6, external and internal auditors are compared using simple averages of the factors for both the CEOs, Directors and Operating Performance and Organizational Structure and Control factor groups.

Table 6: Pair-wise Comparisons Using Simple Averages of Factors

\begin{tabular}{|c|c|c|c|c|c|c|c|}
\hline \multirow{4}{*}{$\begin{array}{c}\text { Dependent } \\
\text { Variable }\end{array}$} & \multirow[b]{2}{*}{$\begin{array}{c}\text { Auditor } \\
\text { Type } \\
\text { (I) }\end{array}$} & \multirow[b]{2}{*}{$\begin{array}{c}\text { Auditor } \\
\text { Type } \\
\text { (J) }\end{array}$} & \multirow[b]{2}{*}{$\begin{array}{c}\text { Mean } \\
\text { Difference } \\
(\mathbf{I}-\mathbf{J})\end{array}$} & \multirow[b]{2}{*}{$\begin{array}{c}\text { Std. } \\
\text { Error }\end{array}$} & \multirow[b]{2}{*}{ Sig. } & \multicolumn{2}{|c|}{ 95\% Confidence Interval } \\
\hline & & & & & & $\begin{array}{l}\text { Lower } \\
\text { Bound } \\
\end{array}$ & $\begin{array}{l}\text { Upper } \\
\text { Bound }\end{array}$ \\
\hline & External Auditors & Internal Auditors & $.293 *$ & .128 & .023 & .041 & .546 \\
\hline & External Auditors & Internal Auditors & $.285^{*}$ & .117 & .015 & .055 & .515 \\
\hline
\end{tabular}

In summary, Hypothesis 1 was accepted. Significant or marginally significant differences between external and internal auditors exist for the three following red flag factor groups: (1) CEOs, Directors and Operating Performance, (2) Oversight and Monitoring, and (3) Organizational Structure and Controls. For both the CEOs, Directors and Operating Performance and Organizational Structure and Control factor groups, external auditors perceived these red flags as being more effective in detecting fraud than internal auditors as shown in Table 6 .

In the CEOs, Directors and Operating Performance factor group, the following four Pressure red flags were perceived to be more effective in fraud detection by external auditors than internal auditors: (1) PR-2-1: Management and/or board directors holding significant financial interests in the entity; (2) PR-2-2: Management and/or board directors having personally guaranteed significant debts of the firm; (3) PR-2-3: Recurring negative cash flows from operations or an inability to generate cash flows while reporting earnings and earnings growth; and (4) PR-2-4: Operating losses causing threat of imminent bankruptcy or foreclosure, or hostile takeover.

The following three Opportunity red flags in the Organizational Structure and Controls factor group were perceived to be more effective in fraud detection by external auditors than internal auditors: (1) OP-3-1: High turnover of chief executive officers or board directors; (2) OP-3-2: Overly complex organizational structure involving unusual legal entities or managerial lines of authority; and (3) OP-3-3: Difficulty in determining the organization or individuals that have controlling interest in the entity.

In the Oversight and Monitoring factor group, the following three Opportunity red flags were perceived to have different levels of effectiveness but did not represent significant differences: (1) OP-2-1: Ineffective boards of directors or audit committee oversight over the financial reporting process and internal control system; (2) OP-2-2: Inadequate monitoring of significant internal controls and (3) OP-2-3: High turnover rates or employment of ineffective accounting, internal audit, or information technology staff.

The significant differences between external and internal auditors concerning the level of fraud detecting effectiveness of each of the 36 red flags are similar to the results of the American study. In the United States, numerous significant differences were found between external and internal auditors concerning their perceptions of 
the level of fraud-detecting effectiveness of each of the 42 SAS No. 99 red flags that are required to be used in financial statement audits to detect fraudulent financial reporting activities (Lin et al., 2006; Moyes et al., 2007).

Hypothesis 2: Professional Demographic Factor - Highest Degrees Received by Auditors

In the second hypothesis, it is proposed that differences exist in the perceived level of effectiveness of each of the 36 red flags in fraud detection among the different highest degrees (Associate, Bachelor's, Master's, and $\mathrm{Ph} . \mathrm{D}$.) received by the Iranian auditors. As a professional demographic factor, the highest degrees received by auditors were classified into four different categories: (1) Associate degrees received by 3 auditors, (2) Bachelor's degrees by 132 auditors, (3) Master of Science degrees received by 77 auditors, and (4) Ph.D.s received by 9 auditors. The MANOVA, which used factor scores, is shown in Table 7. As a professional demographic factor, highest degrees received by auditors influence the perceived level of fraud-detecting effectiveness of one red flag factor group known as the Management Decisions and Market Changes, which includes seven red flags that all are significant. In other words, auditors with Master of Science degrees and auditors with Bachelor's degrees perceived each of seven red flags to have different levels of fraud-detecting effectiveness.

Table 7: Tests of Between-Subjects Effects Using Factor Scores

\begin{tabular}{|c|c|c|c|c|c|}
\hline Dependent Variable & $\begin{array}{c}\text { Type III Sum } \\
\text { of Squares }\end{array}$ & df & $\begin{array}{c}\text { Mean } \\
\text { Square }\end{array}$ & $\begin{array}{c}\text { F } \\
\text { Value }\end{array}$ & Sig. \\
\hline PR FacScore1 - Management Decisions \& Market Changes & 12.323 & 3 & 4.108 & 4.262 & .006 \\
\hline
\end{tabular}

In Table 8, the Scheffe test using factor scores compares the Associate degrees with the Bachelor's, Master's and Ph.D. degrees for the seven red flags in the Management Decisions and Market Changes factor group.

Table 8: Multiple Comparisons Using Factor Scores with the Scheffe Test

\begin{tabular}{|c|c|c|c|c|c|c|c|}
\hline \multirow[b]{2}{*}{$\begin{array}{c}\text { Dependent } \\
\text { Variable }\end{array}$} & \multirow[b]{2}{*}{$\begin{array}{c}\text { College } \\
\text { Degree } \\
\text { (I) }\end{array}$} & \multirow[b]{2}{*}{$\begin{array}{c}\text { College } \\
\text { Degree } \\
(\mathbf{J})\end{array}$} & \multirow[b]{2}{*}{$\begin{array}{c}\text { Mean } \\
\text { Difference } \\
\underline{(\mathbf{I}-\mathbf{J})}\end{array}$} & \multirow[b]{2}{*}{$\begin{array}{c}\text { Std. } \\
\text { Error }\end{array}$} & \multirow[b]{2}{*}{ Sig. } & \multicolumn{2}{|c|}{$\begin{array}{l}\text { 95\% Confidence } \\
\text { Interval } \\
\end{array}$} \\
\hline & & & & & & $\begin{array}{l}\text { Lower } \\
\text { Bound }\end{array}$ & $\begin{array}{l}\text { Upper } \\
\text { Bound }\end{array}$ \\
\hline \multirow[t]{3}{*}{$\begin{array}{l}\text { PR FacScore1 -Management } \\
\text { Decisions \& Market Changes }\end{array}$} & \multirow[t]{3}{*}{$\begin{array}{l}\text { Associate } \\
\text { Degree }\end{array}$} & $\begin{array}{l}\text { Bachelor's } \\
\text { Degree }\end{array}$ & 1.0308430 & .57322126 & .359 & -.5842393 & 2.6459253 \\
\hline & & $\begin{array}{l}\text { Master of } \\
\text { Science }\end{array}$ & .6439054 & .57775272 & .743 & -.9839446 & 2.2717553 \\
\hline & & Ph.D. & .3156004 & .65450315 & .972 & -1.5284980 & 2.1596989 \\
\hline
\end{tabular}

The MANOVA, which used simple averages of factor groups, is shown in Table 9. As a professional demographic factor, the highest degrees received by auditors influenced the perceived level of fraud-detecting effectiveness of two red flag factor groups: (1) Management Decisions and Market Changes and (2) Organizational Structure and Controls. These two factor groups included 10 red flags that are all significant.

Table 9: Tests of Between-Subjects Effects Using Simple Averages of Factors

\begin{tabular}{|l|c|c|c|c|c|}
\hline \multicolumn{1}{|c|}{ Dependent Variable } & $\begin{array}{c}\text { Type III Sum } \\
\text { of Squares }\end{array}$ & df & $\begin{array}{c}\text { Mean } \\
\text { Square }\end{array}$ & $\begin{array}{c}\text { F } \\
\text { Value }\end{array}$ & Sig. \\
\hline PR FacAverage1 - Management Decisions \& Market Changes & 6.775 & 3 & 2.258 & 3.470 & .017 \\
\hline OP FacAverage3 - Organizational Structure \& Controls & 6.165 & 3 & 2.055 & 2.857 & .038 \\
\hline
\end{tabular}


In Table 10, the Scheffe test, using simple averages of factors, compares the Associate degrees with the Bachelor's, Master's and Ph.D. degrees for the Management Decisions and Market Changes factor group. For the Organizational Structure and Control Factor group, the Scheffe test, using simple averages of factors, compares the Ph.D. degrees with the Associate's, Bachelor's, and Master's degrees.

Table 10: Multiple Comparisons Using Simple Averages of Factors with the Scheffe Test

\begin{tabular}{|c|c|c|c|c|c|c|c|}
\hline \multirow[b]{2}{*}{$\begin{array}{c}\text { Dependent } \\
\text { Variable }\end{array}$} & \multirow[b]{2}{*}{$\begin{array}{l}\text { College } \\
\text { Degree } \\
\text { (I) }\end{array}$} & \multirow[b]{2}{*}{$\begin{array}{l}\text { College } \\
\text { Degree } \\
\quad(\mathbf{J})\end{array}$} & & \multicolumn{2}{|c|}{ 95\% Confidence Interval } \\
\hline & & & $\begin{array}{l}\text { Mean } \\
\text { Difference } \\
\text { (I-J) }\end{array}$ & $\begin{array}{l}\text { Std. } \\
\text { Error }\end{array}$ & Sig. & $\begin{array}{l}\text { Lower } \\
\text { Bound }\end{array}$ & $\begin{array}{l}\text { Upper } \\
\text { Bound }\end{array}$ \\
\hline \multirow{3}{*}{$\begin{array}{l}\text { PR FacAverage1 - } \\
\text { Management Decisions } \\
\text { \& Market Changes }\end{array}$} & \multirow[t]{3}{*}{$\begin{array}{l}\text { Associate } \\
\text { Degree }\end{array}$} & $\begin{array}{l}\text { Bachelor's } \\
\text { Degree }\end{array}$ & .7676 & .47098 & .449 & -.5591 & 2.0944 \\
\hline & & $\begin{array}{c}\text { Master of } \\
\text { Science Degree }\end{array}$ & .5653 & .47430 & .701 & -.7709 & 1.9014 \\
\hline & & Ph.D. & .0635 & .53781 & 1.000 & -1.4515 & 1.5785 \\
\hline \multirow{3}{*}{$\begin{array}{l}\text { OP FacAverage3- } \\
\text { Organizational Structure and } \\
\text { Control }\end{array}$} & \multirow[t]{3}{*}{ Ph.D } & $\begin{array}{l}\text { Associate } \\
\text { Degree }\end{array}$ & .3704 & .56535 & .934 & -1.2223 & 1.9630 \\
\hline & & $\begin{array}{l}\text { Bachelor's } \\
\text { Degree }\end{array}$ & .7096 & .29208 & .120 & -.1133 & 1.5324 \\
\hline & & $\begin{array}{c}\text { Master of } \\
\text { Science Degree }\end{array}$ & .4794 & .29797 & .461 & -.3600 & 1.3188 \\
\hline
\end{tabular}

In summary, Hypothesis 2 was accepted. Significant differences among the four different types of highest degrees (Associate, Bachelor's, Master's and Ph.D.) received by Iranian auditors exist for the two following red flag factor groups: (1) Management Decisions and Market Changes, and (2) Organizational Structure and Controls. These two factor groups included 10 red flags, which are explained in the following two paragraphs.

For the Management Decisions and Market Changes factor group shown in Tables 8 and 10, the results are explained by the three following statements: (1) Auditors with Associate degrees perceived these red flags as being more effective in detecting fraud than the auditors with Ph.D.s; (2) Auditors with Ph.D.s perceived these red flags as being more effective in detecting fraud than the auditors with Master of Science degrees; and (3) Auditors with Master of Science degrees perceived these red flags as being more effective in detecting fraud than the auditors with Bachelor's degrees. The seven Pressure red flags included in the Management Decisions and Market Changes factor group are: (1) PR-1-1: High vulnerability to rapid changes in technology, product obsolescence, or interest rates; (2) PR-1-2: Excessive pressure on operating management or personnel to meet financial targets (sales and profitability incentive goals) exerted by boards of directors and chief executive officers; (3) PR-1-3: Significant declines in customer demand and increasing business failures in the industry or overall economy; (4) PR-1-4: Need to obtain additional debt or equity financing of major research and development or capital expenditures to stay competitive; (5) PR-1-5: High degree of competition or market saturation accompanied by declining margins; (6) PR-1-6: New accounting, statutory, or regulatory requirements; and (7) PR-1-7: Significant portions of management's compensation, represented by bonuses and stock options, being contingent upon achieving aggressive targets for stock price, operating results, financial position, or cash flow.

For the Organizational Structure and Controls factor group shown in Table 8, the results are explained by the three following statements: (1) Auditors with Ph.D.s perceived these red flags as being more effective in detecting fraud than the auditors with Associate degrees; (2) Auditors with Associate degrees perceived these red flags as being more effective in detecting fraud than the auditors with Master of Science degrees; and (3) Auditors with Master of Science degrees perceived these red flags as being more effective in detecting fraud than the auditors with Bachelor's degrees. The three Opportunity red flags included in the Organizational Structure and Controls factor group are: (1) OP-3-1: High turnover of chief executive officers or board directors; (2) OP-3-2: Overly complex organizational structure involving unusual legal entities or managerial lines of authority; and (3) OP-3: Difficulty in determining the organization or individuals that have controlling interest in the entity. 
Approximately 35 percent of all the auditors surveyed graduated with Master of Science degrees and 4 percent with Ph.D. degrees. In general, the more educated auditors perceived these red flags as being more effective in detecting fraud than the less educated auditors.

Hypothesis 3: Professional Demographic Factor - Areas that the Auditors Majored in at Universities

In the Hypothesis 3, it is proposed that differences exist in the perceived level of effectiveness of each of the 36 red flags in detecting fraud among the different areas that auditors majored in at universities. As a professional demographic factor, the four areas that the Iranian auditors majored in at universities are: (1) 146 auditors majoring in Accounting, (2) 51 auditors majoring in Management, (3) 15 auditors majoring in Economics, and (4) 9 auditors majoring in other areas. The MANOVA, which used factor scores, is shown in Table 11. As a professional demographic factor, areas that auditors majored in at universities influenced the perceived level of fraud-detecting effectiveness of one red flag factor group known as CEOs, Directors and Operating Performance. This factor group includes four Pressure red flags, which are all marginally significant.

Table 11: Tests of Between-Subjects Effects Using Factor Scores

\begin{tabular}{|c|c|c|c|c|c|}
\hline $\begin{array}{c}\text { Dependent } \\
\text { Variable }\end{array}$ & $\begin{array}{c}\text { Type III Sum of } \\
\text { Squares }\end{array}$ & $\begin{array}{c}\text { Mean } \\
\text { Square }\end{array}$ & $\begin{array}{c}\text { F } \\
\text { Value }\end{array}$ & Sig. \\
\hline PR FacScore2 - CEOs, Directors \& Operating Performance & 6.539 & 3 & 2.180 & 2.195 & .090 \\
\hline
\end{tabular}

In Table 12, the Scheffe test, using factor scores, compares the Accounting degrees with the Management, Economics and other degrees for the CEOs, Directors and Operating Performance factor group.

Table 12: Multiple Comparisons Using Factor Scores with the Scheffe Test

\begin{tabular}{|c|c|c|c|c|c|c|c|}
\hline \multirow[b]{2}{*}{$\begin{array}{c}\text { Dependent } \\
\text { Variable }\end{array}$} & \multirow[b]{2}{*}{$\begin{array}{l}\text { University } \\
\text { Major } \\
\text { (I) }\end{array}$} & \multirow[b]{2}{*}{$\begin{array}{l}\text { University } \\
\text { Major } \\
\text { (J) }\end{array}$} & \multirow[b]{2}{*}{$\begin{array}{c}\text { Mean } \\
\text { Difference } \\
\text { (I-J) }\end{array}$} & \multirow[b]{2}{*}{$\begin{array}{l}\text { Std. } \\
\text { Error }\end{array}$} & \multirow[b]{2}{*}{ Sig. } & \multicolumn{2}{|c|}{$95 \%$ Confidence Interval } \\
\hline & & & & & & $\begin{array}{l}\text { Lower } \\
\text { Bound }\end{array}$ & $\begin{array}{l}\text { Upper } \\
\text { Bound }\end{array}$ \\
\hline \multirow{3}{*}{$\begin{array}{l}\text { PR FacScore2 - } \\
\text { CEO, Directors } \\
\text { \& Operating } \\
\text { Performance }\end{array}$} & \multirow[t]{3}{*}{ Accounting } & Management & .3409121 & .16208796 & .222 & -.1157796 & .7976038 \\
\hline & & Economics & .4005613 & .27019048 & .534 & -.3607151 & 1.1618378 \\
\hline & & Others & .4121774 & .34225305 & .694 & -.5521393 & 1.3764941 \\
\hline
\end{tabular}

In summary, Hypothesis 3 was accepted. Significant differences exist among the four different areas that Iranian auditors majored in at universities for the red flag factor group known as CEOs, Directors and Operating Performance. As shown in Table 10, the results are explained by the three following statements: (1) Auditors who majored in Accounting perceived these red flags as being more effective in detecting fraud than the auditors who majored in Management; (2) Auditors who majored in Management perceived these red flags as being more effective in detecting fraud than the auditors who majored in Economics; and (3) Auditors who majored in Economics perceived these red flags as being more effective in detecting fraud than the auditors who majored in other areas. This factor group, known as CEOs, Directors and Operating Performance, includes four Pressure red flags: (1) PR-2-1: Management and/or board directors holding significant financial interests in the entity; (2) PR-22: Management and/or board directors have personally guaranteed significant debts of the firm; (3) PR-2-3: Recurring negative cash flows from operations or an inability to generate cash flows while reporting earnings and earnings growth; and (4) PR-2-4: Operating losses causing threat of imminent bankruptcy or foreclosure, or hostile takeover.

Two-thirds of the auditors surveyed majored in Accounting. The results concerning the different majors of the Iranian auditors are summarized in the four following statements: (1) Auditors who majored in Accounting perceived the four Pressure red flags as having the highest fraud detecting effectiveness; (2) Auditors majoring in 
Management perceived these red flags as having the second highest fraud detecting effectiveness; (3) Auditors majoring in Economics perceived these red flags as having the third highest fraud detecting effectiveness; and (4) Auditors majoring in other areas perceived these red flags as having the least fraud detecting effectiveness.

Hypothesis 4: Professional Demographic Factor - Auditors’ Accumulated Knowledge about Red Flags

In the fourth hypothesis, it is proposed that differences exist in the perceived level of effectiveness of each of the 36 red flags in fraud detection among the different levels of auditors' accumulated knowledge about red flags. As a professional demographic factor, the various levels of knowledge about red flags accumulated by the Iranian auditors are classified into four different categories: (1) complete knowledge about red flags by 51 auditors, (2) limited knowledge about red flags by 106 auditors, (3) minimum knowledge about red flags by 28 auditors, and (4) no knowledge about red flags by 36 auditors. The MANOVA, which used factor scores, is shown in Table 13. As a professional demographic factor, the knowledge of red flags accumulated by auditors influences the perceived level of fraud-detecting effectiveness of two red flag factor groups known as: (1) Management Decisions and Market Changes, and (2) Management Involvement. The 11 red flags were included in these two factor groups are all marginally significant.

Table 13: Tests of Between-Subjects Effects Using Factor Scores

\begin{tabular}{|l|c|c|c|c|c|}
\hline \multicolumn{1}{|c|}{ Dependent Variable } & $\begin{array}{c}\text { Type III Sum of } \\
\text { Squares }\end{array}$ & df & $\begin{array}{c}\text { Mean } \\
\text { Square }\end{array}$ & $\begin{array}{c}\text { F } \\
\text { Value }\end{array}$ & Sig. \\
\hline PR FacScore1 - Management Decisions \& Market Changes & 6.575 & 3 & 2.192 & 2.213 & .088 \\
\hline RA FacScore2 - Management Involvement & 7.082 & 3 & 2.361 & 2.387 & .070 \\
\hline
\end{tabular}

In Table 14, the Scheffe test, using factor scores, compares complete knowledge about red flags accumulated by auditors with the limited knowledge, minimum knowledge, and no knowledge about red flags accumulated by other auditors for the two factor groups: (1) Management Decisions and Market Changes, and (2) Management Involvement.

Table 14: Multiple Comparisons Using Factor Scores with the Scheffe Test

\begin{tabular}{|c|c|c|c|c|c|c|c|}
\hline \multirow[b]{2}{*}{$\begin{array}{c}\text { Dependent } \\
\text { Variable }\end{array}$} & \multirow[b]{2}{*}{$\begin{array}{l}\text { Knowledge } \\
\text { (I) }\end{array}$} & \multirow[b]{2}{*}{$\begin{array}{c}\text { Knowledge } \\
(\mathbf{J})\end{array}$} & \multirow[b]{2}{*}{$\begin{array}{l}\text { Mean Difference } \\
\text { (I-J) }\end{array}$} & \multirow[b]{2}{*}{$\begin{array}{l}\text { Std. } \\
\text { Error }\end{array}$} & \multirow[b]{2}{*}{ Sig. } & \multicolumn{2}{|c|}{$95 \%$ Confidence Interval } \\
\hline & & & & & & $\begin{array}{l}\text { Lower } \\
\text { Bound }\end{array}$ & $\begin{array}{l}\text { Upper } \\
\text { Bound }\end{array}$ \\
\hline \multirow{3}{*}{$\begin{array}{l}\text { PR FacScore1 - } \\
\text { Management } \\
\text { Decisions \& Market } \\
\text { Changes }\end{array}$} & \multirow[t]{3}{*}{$\begin{array}{c}\text { Complete } \\
\text { Knowledge }\end{array}$} & $\begin{array}{l}\text { Limited } \\
\text { Knowledge }\end{array}$ & .2605483 & .16959092 & .502 & -.2172834 & .7383800 \\
\hline & & $\begin{array}{l}\text { Minimum } \\
\text { Knowledge }\end{array}$ & .0563062 & .23406703 & .996 & -.6031905 & .7158029 \\
\hline & & $\begin{array}{c}\text { No } \\
\text { Knowledge }\end{array}$ & .5174279 & .21662775 & .130 & -.0929326 & 1.1277885 \\
\hline \multirow{3}{*}{$\begin{array}{l}\text { RA FacScore 2 - } \\
\text { Management } \\
\text { Involvement }\end{array}$} & \multirow[t]{3}{*}{$\begin{array}{c}\text { Complete } \\
\text { Knowledge }\end{array}$} & $\begin{array}{l}\text { Limited } \\
\text { Knowledge }\end{array}$ & .3566129 & .16947287 & .222 & -.1208862 & .8341120 \\
\hline & & $\begin{array}{l}\text { Minimum } \\
\text { Knowledge }\end{array}$ & -.0704613 & .23390409 & .993 & -.7294989 & .5885762 \\
\hline & & $\begin{array}{c}\text { No } \\
\text { Knowledge }\end{array}$ & .3090329 & .21647695 & .566 & -.3009028 & .9189686 \\
\hline
\end{tabular}

The MANOVA, which used simple averages of factor groups, is shown in Table 15. The different amounts of accumulated knowledge of red flags by auditors influence the perceived level of fraud-detecting effectiveness of four red flag factor groups, which includes 22 red flags that are all significant. In Table 15, the two factor groups associated with the professional demographic factor labeled as the auditors' accumulated knowledge about red flags 
are as follows: (1) Management Decisions and Market Changes, (2) Organizational Structure and Controls, (3) Auditors and Managers, and (4) Management Involvement.

Table 15: Tests of Between-Subjects Effects Using Simple Averages of Factors

\begin{tabular}{|l|c|c|c|c|c|}
\hline \multicolumn{1}{|c|}{ Dependent Variable } & $\begin{array}{c}\text { Type III Sum } \\
\text { of Squares }\end{array}$ & df & $\begin{array}{c}\text { Mean } \\
\text { Square }\end{array}$ & $\begin{array}{c}\text { F } \\
\text { Value }\end{array}$ & Sig. \\
\hline PR FacAverage1 - Management Decisions \& Market Changes & 5.061 & 3 & 1.687 & 2.566 & .055 \\
\hline OP FacAverage3 - Organizational Structure Control & 9.446 & 3 & 3.149 & 4.311 & .006 \\
\hline RA FacAverage1 - Auditors \& Managers & 5.814 & 3 & 1.938 & 2.903 & .036 \\
\hline RA FacAverage2 - Management Involvement & 7.909 & 3 & 2.636 & 3.111 & .027 \\
\hline
\end{tabular}

Table 16 shows that most of the significance is explained by: (1) the differences between auditors with complete knowledge of red flags and auditors with limited knowledge of red flags, and (2) the differences between auditors with complete knowledge of red flags and auditors with no knowledge of red flags. The four following factor groups, associated with the professional demographic factor labeled as the auditors' accumulated knowledge about red flags, are illustrated in Table 16: (1) Management Decisions and Market Changes, (2) Organizational Structure and Controls, (3) Auditors and Managers, and (4) Management Involvement.

Table 16: Multiple Comparisons Using Simple Averages of Factors with the Scheffe Test

\begin{tabular}{|c|c|c|c|c|c|c|c|}
\hline \multirow[b]{2}{*}{$\begin{array}{c}\text { Dependent } \\
\text { Variable }\end{array}$} & \multirow[b]{2}{*}{$\begin{array}{c}\text { Knowledge } \\
\text { (I) }\end{array}$} & \multirow[b]{2}{*}{$\begin{array}{c}\text { Knowledge } \\
(\mathrm{J})\end{array}$} & \multirow[b]{2}{*}{$\begin{array}{l}\text { Mean } \\
\text { Difference } \\
\quad(\mathbf{I}-J)\end{array}$} & \multirow[b]{2}{*}{$\begin{array}{l}\text { Std. } \\
\text { Error }\end{array}$} & \multirow[b]{2}{*}{ Sig } & \multicolumn{2}{|c|}{$\begin{array}{l}\text { 95\% Confidence } \\
\text { Interval }\end{array}$} \\
\hline & & & & & & $\begin{array}{l}\text { Lower } \\
\text { Bound } \\
\end{array}$ & $\begin{array}{l}\text { Upper } \\
\text { Bound }\end{array}$ \\
\hline \multirow{3}{*}{$\begin{array}{l}\text { PR FacAverage1 - Management } \\
\text { Decisions } \\
\text { \& Market Changes }\end{array}$} & \multirow{3}{*}{$\begin{array}{l}\text { Complete } \\
\text { Knowledge }\end{array}$} & Limited Knowledge & .2625 & .13599 & .295 & -.1206 & .6456 \\
\hline & & Minimum Knowledge & .0698 & .18526 & .986 & -.4521 & .5916 \\
\hline & & No Knowledge & .4364 & .17512 & .105 & -.0569 & .9297 \\
\hline \multirow{3}{*}{$\begin{array}{l}\text { OP FacAverage } 3 \text { - } \\
\text { Organizational Structure \& } \\
\text { Controls }\end{array}$} & \multirow{3}{*}{$\begin{array}{l}\text { Complete } \\
\text { Knowledge }\end{array}$} & Limited Knowledge & $.4112^{*}$ & .14333 & .044 & .0075 & .8149 \\
\hline & & Minimum Knowledge & .2711 & .19525 & .588 & -.2790 & .8211 \\
\hline & & No Knowledge & $.6118^{*}$ & .18457 & .013 & .0919 & 1.1317 \\
\hline \multirow{3}{*}{$\begin{array}{l}\text { RA FacAverage1 - Auditors \& } \\
\text { Managers }\end{array}$} & \multirow{3}{*}{$\begin{array}{l}\text { Complete } \\
\text { Knowledge }\end{array}$} & Limited Knowledge & .3714 & .13705 & .065 & -.0146 & .7575 \\
\hline & & Minimum Knowledge & .1608 & .18670 & .863 & -.3651 & .6868 \\
\hline & & No Knowledge & .3886 & .17648 & .186 & -.1085 & .8858 \\
\hline \multirow{3}{*}{$\begin{array}{l}\text { RA FacAverage2 - } \\
\text { Management Involvement }\end{array}$} & \multirow{3}{*}{$\begin{array}{l}\text { Complete } \\
\text { Knowledge }\end{array}$} & Limited Knowledge & .3838 & .15439 & .106 & -.0511 & .8187 \\
\hline & & Minimum Knowledge & .0574 & .21032 & .995 & -.5351 & .6499 \\
\hline & & No Knowledge & .4602 & .19882 & .151 & -.0999 & 1.0202 \\
\hline
\end{tabular}

In summary, Hypothesis 4 was accepted. Significant differences among the four different amounts of accumulated knowledge about red flags by auditors exist for the four following red flag factor groups: (1) Management Decisions and Market Changes, (2) Organizational Structure and Controls, (3) Auditors and Managers, and (4) Management Involvement. These four factor groups included 22 red flags which are explained in the following four paragraphs. The four different amounts of accumulated knowledge about red flags by auditors are significant with respect to the level of fraud-detecting effectiveness of the red flags as perceived by auditors.

For the Management Decisions and Market Changes factor group shown in Tables 14 and 16, the results are explained by the three following statements: (1) Auditors with complete knowledge of red flags perceived these red flags as being more effective in detecting fraud than the auditors with minimum knowledge of red flags; (2) 
Auditors with minimum knowledge of red flags perceived these red flags as being more effective in detecting fraud than the auditors with limited knowledge of red flags; and (3) Auditors with limited knowledge of red flags perceived these red flags as being more effective in detecting fraud than the auditors with no knowledge of red flags. The seven Pressure red flags included in the Management Decisions and Market Changes factor group are: (1) PR-11: High vulnerability to rapid changes in technology, product obsolescence, or interest rates; (2) PR-1-2: Excessive pressure on operating management or personnel to meet financial targets (sales and profitability incentive goals) exerted by board of directors and chief executive officers; (3) RP-1-3: Significant declines in customer demand and increasing business failures in the industry or overall economy; (4) PR-1-4: Need to obtain additional debt or equity financing of major research and development or capital expenditures to stay competitive; (5) PR-1-5: High degree of competition or market saturation accompanied by declining margins; (6) PR-1-6: New accounting, statutory, or regulatory requirements; and (7) PR-1-7: Significant portions of management's compensation, represented by bonuses and stock options, being contingent upon achieving aggressive targets for stock price, operating results, financial position, or cash flow.

For the Organizational Structure and Control factor group as shown in Table 16, the results are explained by the three following statements: (1) Auditors with complete knowledge of red flags perceived these red flags as being more effective in detecting fraud than the auditors with minimum knowledge of red flags; (2) Auditors with minimum knowledge of red flags perceived these red flags as being more effective in detecting fraud than the auditors with limited knowledge of red flags; and (3) Auditors with limited knowledge of red flags perceived these red flags as being more effective in detecting fraud than the auditors with no knowledge of red flags. The three Opportunity red flags included in the Organizational Structure and Control factor group are: (1) OP-3-1: High turnover of chief executive officers or board directors; (2) OP-3-2: Overly complex organizational structure involving unusual legal entities or managerial lines of authority; and (3) OP-3-3: Difficulty in determining the organization or individuals that have controlling interest in the entity.

For the Auditors and Managers factor group as shown in Table 16, the results are explained by the three following statements: (1) Auditors with complete knowledge of red flags perceived these red flags as being more effective in detecting fraud than the auditors with minimum knowledge of red flags; (2) Auditors with minimum knowledge of red flags perceived these red flags as being more effective in detecting fraud than the auditors with limited knowledge of red flags; and (3) Auditors with limited knowledge of red flags perceived these red flags as being more effective in detecting fraud than the auditors with no knowledge of red flags. The eight Rationalization red flags included in the Auditors and Managers factor group are: (1) RA-1-1: Unreasonable demands on the auditor, such as unreasonable time constraints regarding the completion of the audit or the issuance of the auditor's report; (2) RA-1-2: Frequent disputes with the current or predecessor auditor on accounting, auditing, or reporting matters; (3) RA-1-3: Domineering management behavior in dealing with the auditor, especially involving attempts to influence the scope of the auditor's work; (4) RA-1-4: Formal or informal restrictions on the auditor that inappropriately limit his access to people or information or limit his ability to communicate effectively with the board of directors or the audit committee; (5) RA-1-5: A practice used by management of committing to analysts, creditors, and other third parties to achieve aggressive or unrealistic forecasts; (6) RA-1-6: Known history of violations of securities law, or claims against the entity, its senior management, or board directors alleging fraud or violations of securities laws; (7) RA-1-7: An interest by management in employing inappropriate means to minimize reported earnings for tax-motivated reasons; and (8) RA-1-8: Management failure to correct known reportable conditions in internal controls in a timely basis.

For the Management Involvement factor group shown in Table 14 and 16, the results are explained by the three following statements: (1) Auditors with complete knowledge of red flags perceived these red flags as being more effective in detecting fraud than the auditors with minimum knowledge of red flags; (2) Auditors with minimum knowledge of red flags perceived these red flags as being more effective in detecting fraud than the auditors with limited knowledge of red flags; and (3) Auditors with limited knowledge of red flags perceived these red flags as being more effective in detecting fraud than the auditors with no knowledge of red flags. The four Rationalization red flags included in the Management Involvement factor group are: (1) RA-2-1: Ineffective communication, implementation, support, or enforcement of the entity's values or ethical standards by management or the communication of inappropriate values or ethical standards; (2) RA-2-2: Excessive interest by management in maintaining or increasing the entity's stock price or earnings trend; (3) RA-2-3: Nonfinancial management's 
excessive participation in the selection of accounting principles or the determination of significant estimates; and (4) RA-2-4: Recurring attempts by management to justify marginal or inappropriate accounting on the basis of materiality.

Auditors with complete or limited accumulated knowledge about red flags represented 71 percent of all the respondents surveyed. In contrast, auditors with minimum or no accumulated knowledge about red flags represented 29 percent of the all the respondents surveyed.

Hypothesis 5: Professional Demographic Factor - Have Auditors Used Red Flags to Detect Fraud

In the Hypothesis 5, it is proposed that auditors who have used red flags to detect fraud will have different levels of perceived effectiveness of each of the 36 red flags than auditors who have never used red flags to detect fraud. In this Iranian study, usable red flag questionnaires were completed by 151 auditors who have used red flags to detect fraud and by 68 auditors who have never used red flags to detect fraud. The MANOVA, which used factor scores, is shown in Table 17. As a professional demographic factor, auditors who have or have not used red flags to detect fraud, influenced the perceived level of fraud-detecting effectiveness of four red flag factor groups which includes 20 red flags. The four red flag groups are: (1) Management Decisions and Market Changes, (2) Listing/Debt Requirements \& Profitability, (3) Organizational Structure \& Controls, and (4) Auditors and Managers. Considering these four factor groups, 12 red flags are significant, and eight red flags are marginally significant.

Table 17: Tests of Between-Subjects Effects Using Factor Scores

\begin{tabular}{|l|c|c|c|c|c|}
\hline \multicolumn{1}{|c|}{ Dependent Variable } & $\begin{array}{c}\text { Type III Sum of } \\
\text { Squares }\end{array}$ & df & $\begin{array}{c}\text { Mean } \\
\text { Square }\end{array}$ & $\begin{array}{c}\text { F } \\
\text { Value }\end{array}$ & Sig. \\
\hline PR FacScore1 - Management Decisions \& Market Changes & 5.329 & 1 & 5.329 & 5.373 & .021 \\
\hline PR FacScore3 - Listing/Debt Requirements \& Profitability & 5.196 & 1 & 5.196 & 5.222 & .023 \\
\hline OP FacScore3 - Organizational Structure \& Controls & 8.617 & 1 & 8.617 & 8.983 & .003 \\
\hline RA FacScore1 - Auditors and Managers & 2.916 & 1 & 2.916 & 2.903 & .090 \\
\hline
\end{tabular}

The MANOVA, which used simple averages of factor groups, is shown in Table 18. As a professional demographic factor, auditors who have or have not used red flags to detect fraud, influenced the perceived level of fraud-detecting effectiveness of three red flag factor groups: (1) Management Decisions and Market Changes, (2) Listing/Debt Requirement and Profitability, and (3) Organizational Structure and Controls. These three factor groups include 12 red flags which are all significant.

Table 18: Tests of Between-Subjects Effects Using Simple Averages of Factors

\begin{tabular}{|l|c|c|c|c|c|}
\hline \multicolumn{1}{|c|}{ Dependent Variable } & $\begin{array}{c}\text { Type III Sum of } \\
\text { Squares }\end{array}$ & df & $\begin{array}{c}\text { Mean } \\
\text { Square }\end{array}$ & $\begin{array}{c}\text { F } \\
\text { Value }\end{array}$ & Sig. \\
\hline PR FacAverage1 - Management Decisions \& Market Changes & 3.899 & 1 & 3.899 & 5.904 & .016 \\
\hline PR FacAverage3 - Listing/Debt Requirements \& Profitability & 7.983 & 1 & 7.983 & 7.639 & .006 \\
\hline OP FacAverage3 - Organizational Structure \& Controls & 5.229 & 1 & 5.229 & 7.032 & .009 \\
\hline
\end{tabular}

Table 19 compares auditors who have detected fraud using red flags with auditors who have not detected fraud using red flags for the three factor groups: (1) Management Decisions and Market Changes, (2) Listing/Debt Requirements and Profits, and (3) Organizational Structure \& Controls. 
Table 19: Pairwise Comparisons Using Simple Averages of Factors

\begin{tabular}{|l|c|c|c|c|c|c|l|}
\hline \multicolumn{1}{|c|}{ Dependent Variable } & $\begin{array}{c}\text { Auditor } \\
\text { Detect } \\
\text { Fraud } \\
(\mathbf{I})\end{array}$ & $\begin{array}{c}\text { Auditor } \\
\text { Detect } \\
\text { Fraud } \\
(\mathbf{J})\end{array}$ & $\begin{array}{c}\text { Mean } \\
\text { Difference } \\
(\mathbf{I}-J)\end{array}$ & $\begin{array}{c}\text { Std. } \\
\text { Error }\end{array}$ & Sig. & $\begin{array}{l}\text { 95\% Confidence Interval } \\
\end{array}$ \\
Bound
\end{tabular}$} &{\begin{array}{l}\text { Upper } \\
\text { Bound }\end{array}} \\
{\hline \begin{array}{l}\text { PR FacAverage1 - Management Decisions } \\
\text { \& Market Changes }\end{array}} &{\text { Yes }} &{\text { No }} &{.287^{*}} &{.118} &{.016} &{.054} &{.519} \\
{\hline \begin{array}{l}\text { PR FacAverage3 - Listing/Debt } \\
\text { Requirements \& Profits }\end{array}} &{\text { Yes }} &{\text { No }} &{.410^{*}} &{.148} &{.006} &{.118} &{.703} \\
{\hline \begin{array}{l}\text { OP FacAverage3 - Organizational } \\
\text { Structure \& Controls }\end{array}} &{\text { Yes }} &{\text { No }} &{.332^{*}} &{.125} &{.009} &{.085} &{.579} \\
{\hline} \end{array}$

In summary, Hypothesis 5 was accepted. Significant or marginally significant differences between the auditors who have used red flags to detect fraud and the auditors who have never used red flags influenced different levels of perceived effectiveness of each of the 22 red flags included in the four following red flag factor groups. These four factor groups are: (1) Management Decisions and Market Changes, (2) Listing/Debt Requirements and Profitability, (3) Organizational Structure and Controls, and (4) Auditors and Managers. As shown in Table 19, the auditors who have used red flags to detect fraud perceived these red flags as being more effective in detecting fraud than the auditors who have never used red flags to detect fraud for the three factor groups: (1) Management Decisions and Market Changes, (2) Listing/Debt Requirements and Profits, and (3) Organizational Structure and Controls. The significant differences between auditors who have used red flags to detect fraud and auditors who have never used red flags to detect fraud in the three factors groups is explained in the following three paragraphs.

For the Management Decisions and Market Changes factor group shown in Table 19, auditors who have used red flags to detect fraud perceived seven Pressure red flags as being more effective in detecting fraud than auditors who have never used red flags to detect fraud. The seven Pressure red flags in the Management Decisions and Market Changes factor group are: (1) PR-1-1: High vulnerability to rapid changes in technology, product obsolescence, or interest rates; (2) PR-1-2: Excessive pressure on operating management or personnel to meet financial targets (sales and profitability incentive goals) exerted by board of directors and chief executive officers; (3) PR-1-3: Significant declines in customer demand and increasing business failures in the industry or overall economy; (4) PR-1-4: Need to obtain additional debt or equity financing of major research and development or capital expenditures to stay competitive; (5) PR-1-5: High degree of competition or market saturation accompanied by declining margins; (6) PR-1-6: New accounting, statutory, or regulatory requirements; and (7) PR-1-7: Significant portions of management's compensation, represented by bonuses and stock options, being contingent upon achieving aggressive targets for stock price, operating results, financial position, or cash flow.

For the Listing/Debt Requirements and Profitability factor group shown in Table 19, auditors who have used red flags to detect fraud perceived two Pressure red flags as being more effective in detecting fraud than auditors who have never used red flags to detect fraud. The two Pressure red flags in the Listing/Debt Requirements and Profitability factor group are: (1) PR-3-1: Marginal ability to meet exchange listing requirements or debt repayment; and (2) PR-3-2: Rapid growth or unusual profitability, especially compared to that of other companies in the same industry.

For the Organizational Structure and Control Factor group shown in Table 19, auditors who have used red flags to detect fraud perceived three Opportunity red flags as being more effective in detecting fraud than auditors who have never used red flags to detect fraud. The three Opportunity red flags in the Organizational Structure and Controls factor group are: (1) OP-3-1: High turnover of chief executive officers or board directors; (2) OP-3-2: Overly complex organizational structure involving unusual legal entities or managerial lines of authority; and (3) OP-3-3: Difficulty in determining the organization or individuals that have controlling interest in the entity.

Significant differences, between auditors who have used red flags to detect fraud and auditors who have not used red flags to detect fraud, existed for nine Pressure red flags and three Opportunity red flags. More specifically, auditors who have used red flags to detect fraud perceived these 12 red flags as being more effective in detecting 
fraud than auditors who have never used red flags to detect fraud.

Hypothesis 6: Professional Demographic Factor - Have Auditors Received In-House Red Flag Training

In Hypothesis 6, it is proposed that auditors who have received in-house red flag training will have different levels of perceived effectiveness of each of the 36 red flags than auditors who have not received in-house red flag training. In this study, usable red flag questionnaires were completed from 87 Iranian auditors who have received in-house red flag training, and from 130 Iranian auditors who have never received in-house red flag training. The MANOVA, which used factor scores, is shown in Table 20. As a professional demographic factor, the auditors who have or have not received in-house red flag training influenced the perceived level of frauddetecting effectiveness of three red flag factor groups: (1) Management Decisions and Market Changes, (2) Transactions, Accounts and Estimates, and (3) Auditors and Managers. These three factor groups include 20 red flags which are all significant.

Table 20: Tests of Between-Subjects Effects Using Factor Scores

\begin{tabular}{|l|c|c|c|c|c|}
\hline \multicolumn{1}{|c|}{ Dependent Variable } & $\begin{array}{c}\text { Type III Sum } \\
\text { of Squares }\end{array}$ & df & $\begin{array}{c}\text { Mean } \\
\text { Square }\end{array}$ & $\begin{array}{c}\text { F } \\
\text { Value }\end{array}$ & Sig. \\
\hline PR FacScore1 - Management Decisions \& Market Changes & 8.691 & 2 & 4.345 & 4.412 & .013 \\
\hline OP FacScore1 - Transactions, Accounts \& Estimates & 6.169 & 2 & 3.085 & 3.135 & .046 \\
\hline RA FacScore1 - Auditors \& Managers & 16.885 & 2 & 8.442 & 9.069 & .000 \\
\hline
\end{tabular}

The MANOVA, which used simple averages of factor groups, is shown in Table 21. The auditors who have or have not received in-house red flag training have influenced the perceived level of fraud-detecting effectiveness of six red flag factor groups: (1) Management Decisions and Market Changes, (2) CEOs, Directors and Operating Performance, (3) Transactions, Accounts and Estimates, (4) Organizational Structure and Controls, (5) Auditors and Managers, and (6) Management Involvement. These six factor groups include 31 red flags of which 23 are significant and eight are marginally significant.

Table 21: Tests of Between-Subjects Effects Using Simple Averages of Factors

\begin{tabular}{|c|c|c|c|c|c|}
\hline Dependent Variable & $\begin{array}{c}\text { Type III Sum } \\
\text { of Squares }\end{array}$ & df & $\begin{array}{l}\text { Mean } \\
\text { Square }\end{array}$ & $\begin{array}{c}\mathbf{F} \\
\text { Value }\end{array}$ & Sig. \\
\hline PR FacAverage1 - Management Decisions \& Market Changes & 7.217 & 2 & 3.609 & 5.532 & .005 \\
\hline PR FacAverage 2 - CEO, Directors \& Operating Performance & 4.584 & 2 & 2.292 & 2.537 & .081 \\
\hline OP FacAverage1 - Transactions, Accounts \& Estimates & 7.160 & 2 & 3.580 & 4.924 & .008 \\
\hline OP FacAverage3 - Organizational Structure \& Controls & 4.561 & 2 & 2.280 & 3.022 & .051 \\
\hline RA FacAverage1 - Auditors \& Managers & 12.138 & 2 & 6.069 & 9.562 & .000 \\
\hline RA FacAverage2 - Management Involvement & 4.992 & 2 & 2.496 & 2.880 & .058 \\
\hline
\end{tabular}

Table 22 compares auditors who have received in-house red flag training with auditors who have not received in-house red flag training for the five factor groups: (1) Management Decisions and Market Changes, (2) CEOs, Directors and Operating Performance, (3) Organizational Structure and Controls, (4) Auditors and Managers, and (5) Management Involvement.

In summary, Hypothesis 6 was accepted. Significant or marginally significant differences were found between auditors who have received in-house red flag training and auditors who have not received red flag training. Different levels of effectiveness of the red flags were perceived by auditors, and these red flags are included in the following six red flag factor groups: (1) Management Decisions and Market Changes, (2) CEOs, Directors and Operating Performance, (3) Transactions, Accounts and Estimates, (4) Organizational Structure and Controls, (5) Auditors and Managers and (6) Management Involvement. For the six following factor groups, auditors who have 
received in-house red flag training perceived these red flags as being more effective in detecting fraud than auditors who have never received in-house red flag training as shown in Table 22. The significant differences between auditors who have received in-house red flag training and auditors who have never received in-house red flag training are explained in the six following paragraphs.

Table 22: Pair-wise Comparisons Using Simple Averages of Factors

\begin{tabular}{|c|c|c|c|c|c|c|c|}
\hline \multirow[b]{2}{*}{ Dependent Variable } & \multirow[b]{2}{*}{$\begin{array}{l}\text { Training } \\
\text { (I) }\end{array}$} & \multirow[b]{2}{*}{$\begin{array}{l}\text { Training } \\
\quad(\mathbf{J})\end{array}$} & \multirow{2}{*}{$\begin{array}{c}\text { Mean } \\
\text { Difference } \\
\text { (I-J) }\end{array}$} & \multirow[b]{2}{*}{$\begin{array}{l}\text { Std. } \\
\text { Error }\end{array}$} & \multirow[b]{2}{*}{ Sig. } & \multicolumn{2}{|c|}{ 95\% Confidence Interval } \\
\hline & & & & & & $\begin{array}{l}\text { Lower } \\
\text { Bound }\end{array}$ & $\begin{array}{l}\text { Upper } \\
\text { Bound }\end{array}$ \\
\hline $\begin{array}{l}\text { PR FacAverage1 - Management } \\
\text { Decisions \& Market Changes }\end{array}$ & Yes & No & $.364^{*}$ & .110 & .001 & .147 & .582 \\
\hline $\begin{array}{l}\text { PR FacAverage2 - CEO, Directors \& } \\
\text { Operating Performance }\end{array}$ & Yes & No & $.292^{*}$ & .130 & .025 & .036 & .548 \\
\hline $\begin{array}{l}\text { OP FacAverage3 - Organizational } \\
\text { Structure \& Controls }\end{array}$ & Yes & No & $.282^{*}$ & .119 & .018 & .048 & .516 \\
\hline $\begin{array}{l}\text { RA FacAverage1 - Auditors \& } \\
\text { Managers }\end{array}$ & Yes & No & $.438^{*}$ & .109 & .000 & .223 & .652 \\
\hline $\begin{array}{l}\text { RA FacAverage2 - Management } \\
\text { Involvement }\end{array}$ & Yes & No & $.297^{*}$ & 127 & .020 & .047 & .547 \\
\hline
\end{tabular}

For the Management Decisions and Market Changes factor group shown in Table 22, auditors who received in-house red flag training perceived seven Pressure red flags as being more effective in detecting fraud than auditors who have never received in-house red flag training. The seven Pressure red flags in the Management Decisions and Market Changes factor group are: (1) PR-1-1: High vulnerability to rapid changes in technology, product obsolescence, or interest rates; (2) PR-1-2: Excessive pressure on operating management or personnel to meet financial targets (sales and profitability incentive goals) exerted by boards of directors and chief executive officers; (3) PR-1-3: Significant declines in customer demand and increasing business failures in the industry or overall economy; (4) PR-1-4: Need to obtain additional debt or equity financing of major research and development or capital expenditures to stay competitive; (5) PR-1-5: High degree of competition or market saturation accompanied by declining margins; (6) PR-1-6: New accounting, statutory, or regulatory requirements; and (7) PR1-7: Significant portions of management's compensation, represented by bonuses and stock options, being contingent upon achieving aggressive targets for stock price, operating results, financial position, or cash flow.

For the CEOs, Directors and Operating Performance factor group shown in Table 22, auditors who received in-house red flag training perceived four Pressure red flags as being more effective in detecting fraud than auditors who have never received in-house red flag training. The four Pressure red flags in the CEOs, Directors and Operating Performance factor group are: (1) PR-2-1: Management and/or board directors holding significant financial interests in the entity; (2) PR-2-2: Management and/or board directors have personally guaranteed significant debts of the firm; (3) PR-2-3: Recurring negative cash flows from operations or an inability to generate cash flows while reporting earnings and earnings growth; and (4) PR-2-4: Operating losses causing threat of imminent bankruptcy or foreclosure, or hostile takeover.

For the Transactions, Accounts and Estimates factor group shown in Table 22, auditors who have received in-house red flag training perceived five Opportunity red flags as being more effective in detecting fraud than auditors who have never received in-house red flag training. The five Opportunity red flags in the Transactions, Accounts and Estimates factor group are: (1) OP-1-1: Significant, unusual, or highly complex transactions, especially occurring close to year end that pose difficult "substance over form" questions; (2) OP-1-2: Assets, liabilities, revenues, or expenses based on significant estimates that involve subjective judgments or uncertainties that are difficult to corroborate; (3) OP-1-3: Significant related-party transactions not in the ordinary course of business or with related entities that are not audited or audited by another firm; (4) OP-1-4: Domination of management by a single person or small group in a non-owner-managed business without compensating controls; and (5) OP-1-5: Significant bank accounts or subsidiary or branch operations in tax-haven jurisdictions for which 
there appears to be no clear business justification.

For the Organizational Structure and Control factor group shown in Table 22, auditors who received inhouse red flag training perceived three Opportunity red flags as being more effective in detecting fraud than auditors who have never received in-house red flag training. The three Opportunity red flags in the Organizational Structure and Control factor group are: (1) OP-3-1: High turnover of chief executive officers or board directors; (2) OP-3-2: Overly complex organizational structure involving unusual legal entities or managerial lines of authority; and (3) OP-3-3: Difficulty in determining the organization or individuals that have controlling interest in the entity.

For the Auditors and Managers factor group shown in Table 22, auditors who received in-house red flag training, perceived eight Rationalization red flags as being more effective in detecting fraud than auditors who have never received in-house red flag training. The eight Rationalization red flags in the Auditors and Managers factor group are: (1) RA-1-1: Unreasonable demands on the auditor, such as unreasonable time constraints regarding the completion of the audit or the issuance of the auditor's report; (2) RA-1-2: Frequent disputes with the current or predecessor auditor on accounting, auditing, or reporting matters; (3) RA-1-3: Domineering management behavior in dealing with the auditor, especially involving attempts to influence the scope of the auditor's work; (4) RA-1-4: Formal or informal restrictions on the auditor that inappropriately limit his access to people or information or limit his ability to communicate effectively with the board of directors or the audit committee; (5) RA-1-5: A practice used by management of committing to analysts, creditors, and other third parties to achieve aggressive or unrealistic forecasts; (6) RA-1-6: Known history of violations of securities law, or claims against the entity, its senior management, or board directors alleging fraud or violations of securities laws; (7) RA-1-7: An interest by management in employing inappropriate means to minimize reported earnings for tax-motivated reasons; and (8) RA-1-8: Management failure to correct known reportable conditions in internal controls in a timely basis.

For the Management Involvement factor group shown in Table 22, auditors who received in-house red flag training perceived four Rationalization red flags as being more effective in detecting fraud than auditors who have never received in-house training. The four Rationalization red flags in the Management Involvement factor group are: (1) RA-2-1: Ineffective communication, implementation, support, or enforcement of the entity's values or ethical standards by management or the communication of inappropriate values or ethical standards; (2) RA-2-2: Excessive interest by management in maintaining or increasing the entity's stock price or earnings trend; (3) RA-2-3: Nonfinancial management's excessive participation in the selection of accounting principles or the determination of significant estimates; and (4) RA-2-4: Recurring attempts by management to justify marginal or inappropriate accounting on the basis of materiality.

Significant differences between auditors who have received in-house red flag training and auditors who have not received in-house training existed for 11 Pressure red flags, eight Opportunity red flags, and 12 Rationalization red flags. More specifically, auditors who received in-house red flag training perceived these 31 red flags as being more effective in detecting fraud than auditors who have never received in-house red flag training.

\section{SUMMARY}

\section{Conclusions}

From accepting the first hypothesis, significant differences between external and internal auditors exist for 10 red flags. More specifically, external auditors perceived four Pressure red flags and six Opportunity red flags as being more effective in detecting fraud than internal auditors.

From accepting the second hypothesis, significant differences among the four different types of highest degrees (Associate, Bachelor's, Master's and Ph.D.) received by auditors exist for 10 red flags. In general, the more educated auditors perceived seven Pressure red flags and three Opportunity red flags as being more effective in detecting fraud than the less educated auditors. 
From accepting the third hypothesis, significant differences among the different areas (Accounting, Economics, Management and others) that auditors majored in at universities exist for four red flags. Differences among the college majors influence auditors to perceive each of four Pressure red flags to have a different level of fraud-detecting effectiveness. Auditors who majored in Accounting as university students perceived the red flags to be more effective in detecting fraud than the other auditors who majored in Management, Economics and other areas.

From accepting the fourth hypothesis, significant differences among the four different amounts of knowledge (none, minimum, limited and complete) accumulated about red flags by auditors exist for 22 red flags. In general, auditors with more accumulated knowledge about seven Pressure red flags, three Opportunity red flags, and 12 Rationalization red flags perceived these 22 red flags as being more effective in detecting fraud than auditors with less accumulated knowledge about red flags.

From accepting the fifth hypothesis, significant differences between auditors who have used red flags to detect fraud and auditors who have not used red flags to detect fraud, exist for nine Pressure red flags and three Opportunity red flags. More specifically, auditors who have used red flags to detect fraud perceived these 12 red flags as being more effective in detecting fraud than auditors who have never used red flags to detect fraud.

From accepting the sixth hypothesis, significant differences between auditors who have received in-house red flag training and auditors who have not received in-house training exist for 11 Pressure red flags, eight Opportunity red flags, and 12 Rationalization red flags. More specifically, auditors who received in-house red flag training perceived these 31 red flags as being more effective in detecting fraud than auditors who have never received in-house red flag training.

In conclusion, the level of fraud-detecting effectiveness of each of the 36 red flags in fraud detection is influenced by the following six professional demographic factors: (1) type of auditors, (2) highest degrees received by auditors, (3) areas that auditors majored in at universities, (4) different amounts of knowledge accumulated by auditors about red flags, (5) auditors who have used and have not previously used red flags to detect fraud, and (6) auditors who have received or have not previously received in-house red flag training.

\section{Limitations}

There may be two limitations in this study. First, even though the questionnaire was pre-tested and validated, it is still possible that some misinterpretation of the questions may have occurred with the Iranian auditors surveyed. Initially, red flags are difficult for auditing professionals to understand and use in financial statement audits. In the Iran study, the auditors may have had difficulty with interpreting the red flags, since the red flag questionnaire was translated from English to Iranian language. Second, it is possible that the sample size of 227 auditors may not be representative of the entire population of external and internal auditors in Iran. It is probable that the sample was too small and not completely random.

\section{Implications}

Future implications would be to analyze the data collected from different countries and to compare the results among these different countries. Future methodologies may include the following two procedures. First, exploratory Factor Analysis may be performed to verify whether the data collected from different countries have the same structure. Second, if the structures are similar, confirmatory Factor Analyses in a multi-group analysis may be conducted.

\section{ACKNOWLEDGEMENT}

Ebrahim Vahidi Elysseai 


\section{REFERENCES}

1. Albrecht, W.S., and M. Romney. 1986. Red-Flagging Management Fraud: A Validation. Advances in Accounting, 3: 323-334.

2. American Institute of Certified Public Accountants (AICPA). 2009. Consideration of Fraud in a Financial Statement Audit, Statement on Auditing Standard No. 99, AICPA, New York, NY: 127-159.

3. Apostolou, B., J. M. Hassell, S. A. Webber, and G. E. Sumners. 2001. The Relative Importance of Management Fraud Risk Factors. Behavioral Research in Accounting 13: 1-24.

4. Church, B.K., J.J. McMillan, and A. Schneider. 2001. Detection of Fraudulent Financial Reporting. Journal of Accountancy 192 (September): 99.

5. Gramling, A. A., and P. M. Myers. 2003. Internal Auditors' Assessment of Fraud Warning Signs: Implications for External Auditors. The CPA Journal 73: 20-24.

6. Heiman-Hoffman, V., and K. P. Morgan. 1996. The Warning Signs of Fraudulent Financial Reporting. Journal of Accountancy (October 1996): 75-77.

7. Lin, P., Moyes, G.D., Landry, R.M., and Vicdan, H. 2006. Perceived Effectiveness of SAS No. 99 Red Flags: A Comparison Between External and Internal Auditors. Oil, Gas and Energy Quarterly, (December) 55 (2): 337-351.

8. Moyes, G.D., Lin, P., and Landry, R.M. 2005. Raise the Red Flag. Internal Auditor (October) 62 (5): 47 51.

9. Moyes, G.D. 2006a. The Differences in Perceived Level of Fraud-Detecting Effectiveness of SAS No. 99 Red Flags Between External and Internal Auditors. Journal of Business and Economics Research, (June) 5 (6): 9-25.

10. Moyes, G.D., Lin, P., Landry, R.M., and Vicdan, H. 2006b. Internal Auditors' Perceptions of the Effectiveness of Red Flags to Detect Fraudulent Financial Reporting Activities. Journal of Accounting, Ethics and Public Policy, 6 (1): 1-16.

11. Moyes, G.D., Lin, P., Landry, R.M., and Vicdan, H. 2007. Internal Auditors' Perceptions of the Effectiveness of Red Flags to Detect Fraudulent Financial Reporting. The Icfai Journal of Audit Practice, (October) 4 (4): 40-57 (Article Reprinted from the Journal of Accounting, Ethics and Public Policy by Request of the Editor of Icfai Journal of Audit Practice).

12. Moyes, G.D. 2008. CPAs' Perceptions of Red Flags Used in Detecting Fraud. The Icfai Journal of Audit Practice, (January) 5 (1): 47-60.

13. Pincus, K. V. 1989. The Efficacy of a Red Flags Questionnaire for Assessing the Possibility of Fraud. Accounting, Organizations and Society 14 (1 \& 2): 153-164. 